\title{
Exploration of Ideological and political education based on Chinese traditional culture
}

\author{
Xiaoshi $\mathrm{Xu}^{1, \mathrm{a}}$, Le Gao ${ }^{1, \mathrm{~b}^{*}}$ \\ ${ }^{1}$ Jilin Agricultural University, Changchun,130118, China \\ ${ }^{1 a}$ email: 7833949@qq.com, bemail: 455190927@qq.com \\ Correspondence author: Le Gao
}

Keywords: Chinese traditional culture; Ideological and Political Education; patriotism; approach of education

\begin{abstract}
China's traditional culture is an important spiritual wealth. Its outstanding achievements have important reference significance for the ideological and political work in Colleges and universities. Relying on traditional culture to carry out ideological and political education work, it can realize the cultivation of College Students' correct values, patriotism and moral quality to promote the comprehensive development of College students. The ideological and political education methods were innovated using traditional culture education. Chinese traditional culture and ideological and political education has three ways, such as traditional culture into the classroom, traditional culture into practice, traditional culture into the classroom.
\end{abstract}

\section{Introduction}

Chinese traditional culture is the source of the innovation of Ideological and political education for college students. Promoting the inheritance of traditional culture is advantageous to the improvement of the quality of Higher Education ${ }^{[1]}$. With the continuous development of China's education, ideological and political education into the traditional culture is an important method of Ideological and political education work. Carrying forward the excellent traditional culture and doing well the ideological and political work are not only the inheritance of fine tradition but also the requirement of social development ${ }^{[2]}$. Carry forward the fine traditional culture helps to improve the quality of the college student's ideological, spiritual and cultural taste so as to arouse the students of prosperity and development of the motherland's responsibility.

\section{Relying on traditional culture to strengthen ideological and political education work}

\subsection{The influence of traditional culture on students' values}

The thoughts and views of some western capitalism directly influence college students to set up the correct world outlook, values and outlook on life under the background of global information. College students may deviate from the correct criteria under the influence of western thoughts and the negative information of the network. Strengthen education of traditional culture is conducive to the cultivation of the college students to set up to adapt to the modern society and values, overcome the mammon's, the blind and utilitarian, so as to set up the positive attitude and a healthy attitude towards life.

1.2The influence of traditional culture on cultivation of College Students' Patriotism

China has successfully realized the transition from the planned economy system to the market economy system. The thought of college students has been impacted under the background of economic globalization and the cultural diversity of the world. Some college students have forgotten the national consciousness and national consciousness and lost their sense of belonging and identity to the country. The negative effect of the market economy system transition had a negative effect on the university students' values and outlook on life under the negative effect. Some college students' social responsibility and historical responsibility were weakened. Individual 
students only consider individual development needed but ignored the maintenance of national and social responsibility ${ }^{[3]}$.

1.3 The influence of traditional culture on good moral qualities of College Students

Traditional culture education can improve college student's good moral qualities. It is the development of the spirit of the Chinese nation and the requirement for social development. College students only have good moral qualities to form a noble moral character and the pursuit of a higher realm of life. College students should learn the traditional culture and the spirit of working. Thrifty and hard work is a noble social virtue. The Chinese nation is growing in the thrifty and hard work in life. Students only hold the spirit of hard work in order to achieve success and victory. College students should learn the traditional culture of unremitting self-improvement, pioneering and enterprising spirit. In the traditional culture of China, there emerge a lot of unremitting self-improvement and pioneering figure. The Chinese nation is the unremitting self-improvement and pioneering spirit and enterprising and support a step toward today's great power status. College students should learn the spirit of unity in the traditional culture. The traditional culture of our country fully embodies the spirit of unity of virtue. The growth process of the Chinese nation is the process of unity and struggle of the whole nation. College students should learn the virtues of honesty in traditional culture.

1.4 The influence of traditional culture on the comprehensive development of College Students

All round development is the highest requirement for the development of College Students' personal qualities, and is also the fundamental goal of Ideological and political education. All round development is required to achieve the comprehensive development of College Students' Ideological and moral qualities, scientific, cultural quality and health literacy. The current ideological and political education of college students should focus on the comprehensive development of the improvement. The traditional ideology and culture in our country provides a reference for the ideological and political education and the overall development of college students. The comprehensive development of the quality of college students includes scientific and cultural skills, ideological and ethical standards and health literacy. The spirit of traditional culture also includes the double improvement of material and spiritual culture. The traditional culture education of college students can realize the overall development of college students.

\section{The method of strengthening ideological and political education based on traditional culture}

The ideological and political education method is optimized through the ideological and political education of traditional documents. The effectiveness of Ideological and political education in Colleges and universities depends heavily on the proper educational methods. In the work of Ideological and political education in Colleges and universities, the spirit of "benevolence" in traditional culture can stimulate the students' subjective initiative. Educators need to use enthusiasm to affect college students and Adhere to the "love" spirit, so that students take the initiative to recognize their own mistakes with their own sincerity and love. Believe in College students. Inspire College students. Educators adhere to the spirit of "courtesy" and should always be bound by their educational behavior. Educators should use their own practical action and strong personality to educate the students. The efficiency of Ideological and political work in Colleges and universities is related to the quality of Ideological and political education workers. The team construction of Ideological and political education in Colleges and Universities were Based on the ancient Chinese traditional ideology. Educators have a wide knowledge of traditional culture to improve educational skills. Colleges and universities need to rely on traditional culture and strengthen ideological and political education as the spread of knowledge.

\section{The application of traditional culture in the ideological and political education of College Students}

Chinese traditional culture is the treasure of the Chinese nation for thousands of years. China's traditional culture and ideological and political education of college students have the same 
characteristics, so the application of traditional cultural ideas for education can carry forward the traditional culture and enhance the effectiveness of Ideological and political education.

3.1Traditional culture into the classroom

Chinese traditional culture in college student's awareness is not enough. The main position of traditional culture education is classroom. Ideological and political theory course teaching content is Lenin Mao Zedong, Marx thought, Deng Xiaoping theory, "Three Representatives", Scientific Outlook on Development and other social mainstream thought. These contents are the theoretical achievements of our country's outstanding thinkers, revolutionaries and educators according to the concrete practice of China. Marx doctrine and the Chinese traditional culture are consistent in the way of thinking and a lot of points of view.

3.2 Traditional culture into practice

Practical teaching has been widely used in Ideological and political education as one of the most effective ways to improve the effectiveness of education ${ }^{[4]}$. There are many ways to carry out traditional culture education, such as leading students to visit the historical museum, cultural center, memorial and other venues. The practice of traditional culture and education also includes motivate students to produce historical allusions micro film, writing "Guoxue" impressions, watching the "100 forum" and lectures etc. college students are educated in patriotism, outlook on life and values Through these practical teaching activities.

3.3Traditional culture into the campus

In the construction of campus culture, the integration of traditional culture can transfer positive energy to promote the development of College Students. The integration of traditional culture can be from two aspects of hardware and software. On the hardware, the traditional culture of the campus is built from the aspects of the building and the decoration of various venues. In terms of the software, the traditional culture construction of the campus is carried out from several aspects, such as the cultural idea, the cultural position, the cultural activity, the cultural character and so on.

\section{Conclusions}

It not only improves the ideological and political education, but also brings forward the excellent traditional culture of China after the combination of the traditional culture and the ideological and political education of university students.

\section{Acknowledgement}

Education Department of Jilin province " Twelve five " planning research (ZD14050): The research on the integration of traditional culture into the ideological and political education in Colleges and Universities。

\section{Reference}

[1] Kucharčíková A. The Quality Improvement of the University Education[J]. Procedia - Social and Behavioral Sciences, 2013, 106:2993-3001.

[2] ZHANG Hong-wei. On Lack and Realization of Excellent Traditional Culture Education in Ideological and Political Education of Higher vocational education[J]. Journal of Jishou University, 2010, 2(3):81-82.

[3] Liu L. On the Negative Influence and Countermeasures of Network Culture to College Students' Education of Values[J]. Journal of Xingtai Polytechnic College, 2011, 19(12):1304-1307.

[4] Deng G. Adapt the Creative Ability Requirement, Reform Management Modes of Practical Teaching[C]// E-Product E-Service and E-Entertainment (ICEEE), 2010 International Conference on. IEEE, 2010:1 - 4. 